\title{
The Gradual Encroachment of an Idea: Large Enterprise Groups in China
}

\author{
SARAH EATON
}

\begin{abstract}
This article illuminates the ideational foundations of China's 'large enterprise strategy', an early experiment in China's efforts to employ industrial policy to cultivate a group of state-controlled business groups. Based on archival research, the author argues that Chinese policymakers believed the development of state-owned large enterprises would bring several kinds of benefits, both economic and political. Drawing eclectically from Marxian economics and the history of capitalist development in East Asia, they argued that large enterprises could serve as both engines of domestic development and as safeguards and vanguards in the context of China's re-entry to the global marketplace. These enterprise groups were also seen as key elements in a marketconforming model of state control that senior officials began to envision and plan for as early as the late 1980s. The archival documents also shed light on internal debate in the 1980s and 1990s about the pros and cons of promoting monopolies, the substance of which anticipates much of the current heated discussion about China's 'monopoly industries' (longduan hangye垄断行业).
\end{abstract}

Keywords: China, large enterprise strategy, ideas, state-owned enterprises, monopoly

\section{Introduction}

I am sure that the power of vested interests is vastly exaggerated, compared with the gradual encroachment of ideas. Not, indeed, immediately, but after a certain interval; for in the field of economic and political philosophy there are not many who are influenced by new theories after they are twenty-five or thirty years of age, so that the ideas which civil servants and politicians, and even agitators apply to current events are not likely to be the newest. But, soon or late, it is ideas, not vested interests, which are dangerous for good or evil.

J.M. Keynes, The General Theory of Employment, Interest, and Money, [1936]1997: 383-384 
The last decade has seen a marked increase in scholarship employing the tools of interest group analysis to explain policy outcomes in China (e.g. Kennedy 2005a; Steinberg and Shih 2012; Yang and Li 2008). This is undoubtedly a sign of progress in the study of Chinese political economy. With greatly improved access to archival materials as well as interview subjects, scholars researching interest groups have significantly advanced the painstaking work of prying open the black box of the Chinese state. Unsurprisingly, the state sector has been the focus of much of this recent work (Brødsgaard 2012; Li 2011). In the context of vigorous public debate about the 'advance of the state and retreat of the private sector' (guojin mintui国进民退), as well as ever-louder calls to 'break' state monopolies (dapo longduan打破垄断) in industries dominated by behemoth central state-owned enterprises (SOEs) (yangqi央企), there is considerable practical and academic value in rigorous scholarship that can connect the dots between the policy preferences of powerful players in the state sector and actual policy outcomes.

Yet, we should not lose sight of the fact that politics is about much besides interests. In the category of 'other' factors, ideas, in particular, loom large. While it is true that more than thirty years of reform have created a more 'porous' state (Kennedy 2005b), the People's Republic of China (PRC) remains a steadfastly authoritarian polity in which a relatively small number of people wield enormous power over the national policy agenda. It is in no way naïve to suppose that the ideas such policymakers have about the world around them shape their decision-making. As Blyth (2002: 32) argued in his path-breaking study, ideas 'are important because without having ideas as to how the world is put together, it would be cognitively impossible for agents to act in that world in any meaningful sense.' To date, students of Chinese reform-era political economy have largely neglected consideration of what China's reform-era policymakers actually believe about how economies function and how government ought to position itself in relation to the economy. A notable exception is Heilmann and Shih's (2013) excellent study of the political and ideational factors behind China's embrace of industrial policy. In exchanges with the current crop of China's elite industrial policymakers, the authors 'encountered ways of conceiving economic policies that proved to be quite different from widely shared views in Western media and research communities' (2013: 5).

This article adds to the literature on the ideational foundations of China's emerging market order (e.g. Heilmann and Shih 2013; Steinfeld 2006; Pearson 2005). Its particular focus is the set of ideas behind China's 'large 
enterprise strategy' (variously referred to in documents and studies as da qiye jituan zhanlüe 大企业集团战略 and sometimes as da gongsi zhanlüe 大公司战略 or da jituan zhanlüe 大集团战略). Analysis is based largely on the author's collection of dozens of internal (neibu内部) government documents and analyses drawn from an issue-by-issue review of Jingji Yanjiu Cankao Ziliao (Reference Materials for Economic Research), Neibu Wengao (Internal Manuscripts) and Gaige Neican (Internal Documents on Reform) between 1985 and 2002. ${ }^{1}$ The primary advantage of using these neibu materials to study the ideas behind the large enterprise strategy is that, because the intended audience for these pieces consisted of other officials and scholar-officials, their 'political colour' (zhengzhi secai 政治 色彩) is much less strong than documents written for public consumption. Indeed, these documents have much to reveal about the various economic and political functions that policymakers hoped state-owned large enterprises would serve.

\section{The Large Enterprise Strategy: Aims and Policies}

The large enterprise group strategy developed out of early reform-era policy experimentation aimed at improving China's productive capacity in industry. ${ }^{2}$ The immediate precursor to the large enterprise group strategy was the 'horizontal economy' (hengxiang jingji横向经济) initiative (Zhou 1995: 2). Policymakers hoped to partially liberate industrial production from the constraints of the tiao kuai (条块) administrative system by encouraging enterprises in different segments of industry and in different regions to form alliances with one another. In a 1985 People's Daily editorial, the horizontal economy was described as a critical element of correcting 'overcentralization and rigidity' in industry as well as laying the groundwork for an economic system more in tune with the global economy:

[Under the command economy] everybody was 'eating from the common pot' $^{-}$enterprises relied on the state, employees relied on enterprises. This became the common feature of the vertical management structure. To overcome this fault, we must, in urban reform, firmly open the doors not only externally [to the world] but also internally [between enterprises], to facilitate all kinds of horizontal economic integration and affiliation among enterprises, eradicate the closely confined, rigid vertical management structure of the past, and gradually establish an economic structure characterized by open, multilateral economic networks. (Tong and Song 1986: 27)

In its early phases, the large enterprise group strategy (qiye jituan zhanlüe企业集团战略）really served as an extension of these efforts to 
dismantle the Mao-era system. In the mid-1980s, Ma Hong from the State Council Development Research Centre (SCDRC) took the lead in a dialogue with industry leaders in the automobile sector chafing under the constraints imposed by a massive bureaucracy that touched on every aspect of their business. On the basis of recommendations outlined in an SCDRC report, in 1987, the State Council formally designated Dongfeng Motor Company (dongfeng qiche gongsi 东风汽车 公司) a 'discrete planning unit' (jihua danlie 计划单列), which meant a significant repositioning in the planning system. Instead of taking their marching orders from an industrial line ministry, Dongfeng was under the direct authority of the central State Planning Commission (SPC); it was hoped that elimination of this one especially thick layer of bureaucracy would enhance the automaker's 'enterprise autonomy'. The same privilege was gradually extended to a small number of other manufacturing enterprises in the late 1980s.

In the conservative political atmosphere that followed the Tiananmen crisis, Premier Li Peng emerged as a powerful champion of the large enterprise group strategy. Li's support stood in some contrast to the views of his predecessor, Zhao Ziyang, whom Ma Hong (1989: 2) had publicly criticized for 'not attach[ing] importance to large enterprises and not support[ing] their development and technological transformation' while 'g[iving] TVEs special privileges'. As part of an omnibus SOE reform program, the State Council announced, in September 1991, that 100 enterprises were to be selected as 'pilot' large enterprise groups. Pilot enterprises would be accorded jihua danlie status and would be supported by the state through other measures including expansion of import/export rights and provision of preferential loans. The initial 55 pilot enterprises were selected in protracted negotiations between the industrial line ministries and the SPC as well as the State Commission for Restructuring Economic Systems (SCRES). In 1997, a further 63 enterprise groups were added to the ranks of the trial enterprises, which collectively had come to be known as the 'national team' (guojia dui国家队).

While there are a number of careful studies of the successes and failures of the large enterprise strategy in the field of economics (Sutherland 2003; Sutherland and Guest 2010; Nolan 2001), there is little work exploring the ideational underpinnings of these initiatives. Without such knowledge, it is difficult to approach questions of central importance, namely why did Chinese policymakers embrace the large enterprise strategy? What did they hope to achieve? Of course, ideas are far from the only determinants of political decision-making; interests were certainly 
germane to the development of large state-owned enterprises in Chinese industry (e.g. Eaton 2013). And yet, ideas are not always simply cloaks for interest. In the remainder of the article, the ideas behind the 'gradual encroachment' of the large enterprise group strategy are explored.

\section{Products and Engines of Development}

Internal documents show that proponents of the large enterprise strategy advanced theoretically eclectic, but relatively consistent views about the benefits of large enterprises for China's economic development. Several early contributions outlining the case for industrial policy in support of large enterprise development drew from the Marxian concept of 'monopoly capitalism' in characterizing large enterprises as the 'inevitable product' (biran chanwu 必然产物) of capitalist development (Sun 1987: 4 ). One document, written by an official from the SCRES - the central bureaucracy with primary responsibility for large enterprise experimentation in the late 1980s - argued that the path charted by advanced capitalist countries could, indeed should, serve as inspiration for China's reform pathway:

When capitalism experienced large-scale production and the centralization of capital, namely after the merger of enterprises, the transition from free competition to monopoly was realized. This period produced short-term price agreements, cartels, syndicates, and concerns. Today, these organizations still continue to develop and evolve. The economic organization of socialism is also in accord with this rule. Economic system reform and horizontal combinations have resulted in a great liberation of China's productive forces. Industrial development is now being reorganized along the lines of specialization, collaboration and alliance-formation. Thus, the production of a new type of enterprise group fully complies with the laws of economic development. (Sun 1987: 4)

Proponents of the large enterprise strategy looked to advanced capitalist countries for inspiration, but the 'laws of economic development' they induced from their Marxist reading of economic history are strikingly dissimilar from the 'laws' then on offer in much of the capitalist world. At the same time that policymakers in Thatcher's Britain and Reagan's America were intent on dragging government out of the marketplace in an effort to recover a (perhaps mythic) era of free competition, these senior Chinese officials had a very different causal story guiding their interventions. To them, capitalism's triumphs had come not from the flourishing of free competition but rather from its subsequent extinguishment by the advance of big business. 
If economic history offered the conclusion that large enterprises were at once the inevitable and desirable products of economic development, the example set by large enterprises in Asia's developmental states provided Chinese policymakers with ready models and benchmarks with which to guide their own use of industrial policy to hasten the process of large enterprise formation and development. The assembled documents show that officials carefully studied a number of Asian countries' experience with large enterprise groups. One issue of Jingji Yanjiu Cankao Ziliao, published in August 1995, compared the experience of various Asian countries' with large enterprise groups at close range and presented policy-relevant conclusions for China.

In these studies, Japan's experience was a particularly important reference point. A number of them present the view that Japan's post-war development had been led, to large degree, by its six large enterprise groups (Li 1989; Xü 1989). One article argued, on the basis of the Japanese case, that increasing industrial concentration resulting from large enterprise development need not lead to 'stagnation' (tingzhi 停滞) or 'decadence' (fuxiu 腐朽). The writer argued that 'the formation and development of enterprise groups in Japan involved the reassembly of monopoly capital in accordance with the objective requirements of large-scale socialized production' (Kang 1989: 9). And, by 'adjusting the relations of production, so as to better adapt to the objective needs of the development of social productive forces,' these enterprise groups 'played a huge role in promoting economic development in post-war Japan' (ibid). Instead of becoming leeches on the state, the author argued, Japan's kereitsu remained faithful servants to the cause of economic development: they helped the government maintain 'macro control' of the economy in the high-growth period; intensified competition in both domestic and international markets; and stimulated rapid increases in investment and exports (Kang 1989: 9-11).

Officials also hoped that the formation of large enterprise groups would help to alleviate some nagging problems of socialism with Chinese characteristics. They expressed optimism that the large enterprise strategy would reduce high levels of fragmentation in key industries, a legacy of the 'large and complete, small and complete' (da er quan, xiao er quan 大而全, 小而全) structure of the command economy. One piece, written by SCRES officials in 1987, lamented the 'irrational' structure of the auto industry in which there were 100 auto factories and 2,000 spare parts production companies nationwide (Yin and Jia 1987:4). The authors argued in favour of bringing this productive capacity under 
control of the three largest automakers then being added to the jihua danlie system. Relatedly, as a consequence of the typically small scale of enterprises in many domains of China's cellular industry, unrealized economies of scale were common, a problem that officials hoped the expansion of enterprise groups would rectify (e.g. Zhang and Liang 1995; Liu 1996).

\section{Key Elements of a Market-conforming Model of State Control}

This collection of internal documents also sheds light on conceptual links between the large enterprise strategy and officials' broader concerns about how the Party-state could best maintain control of a liberalizing economy. As Heilmann and Shih (2013: 21) have argued, the study of Chinese economic reform outside of China has often been framed by a distorting 'plan to market narrative' that has served to obscure the significance of influential policymakers' deeply held and widely shared beliefs in 'active governmental guidance of the economy.' The 1990s were witness to a slew of sweeping marketizing initiatives, yet it is profoundly misleading to characterize this complex process as simply a triumph of market over plan. At the same time that these reforms were being rolled out, senior policymakers were engaged in vigorous discussion and planning for establishment of a market-conforming model of state control in an open economy. And large enterprise groups, particularly the 'pilot' enterprises, had pride of place in these plans.

A recurring theme in these documents is the emphasis placed on large enterprises as key instruments of state control in a rapidly changing marketplace. In the first phase of the large enterprise strategy, the priority on state control was explicit and heavy handed. Early experiments were bound by the 'three no changes principle' (san bu bian yuanze三不 变原则): relationships of formal subordination would not change (lishu guanxi bu bian隶属关系不变), the financial system would not change (caizheng tizhi bu bian财政体制不变) and the form of ownership (i.e. state ownership) would not change (suoyouzhi xingshi bu bian所有制形式不变) (Zhou 1995: 2). After the formal designation of China as a socialist market economy at the 14th Party Congress in 1992, the stricture on maintaining absolute state ownership of large enterprises was relaxed and SOEs were encouraged to restructure as shareholding companies. A number of high-profile share offerings on overseas stock markets in this period seemed to signal a commitment to gradual privatization of state assets. 
Yet, close witnesses to the process argue that while senior policymakers certainly hoped that exposure to the stock market would invigorate SOEs and compel them to adapt to the rules of the market economy, there was never an intention to cede control of these national champions to private or foreign investors (Walter and Howie 2010, 2006).

Amidst these reforms in the early 1990s, policymakers increasingly looked to another Asian state for guidance in the ways of achieving meaningful 'government-enterprise separation' (zhengqi fenkai政企分 开) alongside continued firm state control of the economy. In an internal document detailing myriad problems with large enterprise groups stemming from continued government meddling in enterprise affairs, analysts from the China Merchants Group argued that Singapore held ready lessons for China:

At the moment, there is much discussion of how to achieve governmententerprise separation with SOEs as the main entities in the management system of enterprise groups...In this regard, there is a lot we can learn from Singapore's experience. Singapore's state-owned enterprise economy occupies an important position in the national economy, and is known throughout the world to operate effectively. Its success is evident in the separation between management of state assets and enterprise operations, that is, government-enterprise separation. Singapore's state-owned economy is largely based on the government's establishment of four large holding companies as the core and with enterprise groups composed of governmentlinked companies. (Zhang and Liang 1995: 20-21)

In the years since, policymakers have drawn inspiration from both elements of the Singapore model - the commanding position of the state economy and the approach to government-enterprise separation. In ongoing debate over China's evolving approach to state asset management, there has been frequent reference to Singapore as there has been in discussions of how China can foster a fleet of state-owned national champions (Eaton 2011).

Policymakers also expressed the view that the development of large enterprise groups would aid the central government's efforts to replace the traditional planning system with a market-conforming 'macro-control' system overseen by the SPC (cf. Heilmann and Shih 2013: 7). An SPC official described the objective of this system transformation as: 'the state regulates (tiaokong调控) the market, the market guides (yindao引 导) the enterprise' (Xing 1988: 17). As the planning apparatus retracted its tentacles from the chain of production and shifted towards regulating the market, insiders argued that large enterprise groups would be an important lynchpin of state control in the revamped system. In 
particular, the gradual replacement of fragmented market structures populated by thousands of small players with industries dominated by a small number of large enterprise groups would significantly improve the effectiveness of government regulation of the economy (Kang 1989; Zhou 1995; Chen 1995).

Similar reasoning was applied to discussion about the exercise of state control in a trimmed-down state sector. In policy debate about the appropriate domain of the 'state-owned economy' (guoyou jingji国有经 济) that began in earnest in the mid-1990s, large enterprise groups again featured prominently in the policy discussion. At the same time that non-state enterprises established a firm footing in many industries, the central government began to consider how the state economy could continue to exercise a 'leading force' (zhudao liliang 主导力量) in the economy, a role mandated by the PRC's constitution. ${ }^{3}$ A 1994 internal report by researchers in the State Council noted that, at the time, there were two views on what 'leading force' actually meant: one camp argued that the state need only control certain key sectors of the economy in order to provide a 'leading force', while others thought that the state would have to retain control of a large proportion of the entire economy in order to meaningfully fulfil this role (Guowuyuan Yanjiushi Ketizu 1994: 27). At the time, the State Council report endorsed the latter view, though senior policymakers subsequently leaned toward the former, commanding heights view at the 15th Party Congress (1997). The state's plan for 'adjusting the layout of the state-owned economy' outlined at the 15th Party Congress stated that the state need only retain a firm 'controlling force' (kongzhili控制力) in 'lifeline industries' (mingmai hangye命脉行业) and 'critical areas' (guanjian lingyu关键领域). In the ensuing discussion about how the state ought to enhance its controlling force in priority industries, the development and expansion of state-owned large enterprises was described as an important method. One internal report suggested that, as large state-owned business groups increased in size, they would ultimately come to control the domestic market and play a vanguard role in Chinese enterprises' expansion into global markets (Sheng 1997: 3).

\section{Safeguards and Vanguards in Global Competition}

In the context of China's gradual opening to the global market, large enterprise groups were also depicted as a means of mitigating the attendant risks of liberalization at home and reaping new opportunities abroad. China's General Agreement on Tariffs and Trade re-entry ne- 
gotiations began in the mid-1980s, but the phase of deep liberalization dates to 1995 when the leadership signalled its commitment to a course of tariff reductions and relaxation of foreign investment rules to support its bid to join the World Trade Organization (WTO). The final WTO Accession Agreement included unprecedented concessions in agriculture and finance, among other sectors. Yet, behind this outward display of commitment to principles of open, liberal economics, there was much internal discussion about how the state should adapt to openness.

In these uncertain times, large enterprises were described in some internal documents as providing a line of defence against foreign encroachment in the home market. The 1994 State Council report on the state-owned economy mentioned above, noted that one of the rationales for supporting the development of large SOEs was China's increased vulnerability to foreign control of the economy due to the frailty of the non-state sector: 'In the context of a high degree of economic openness, in which market competition is intense and the private sector is weak, large state-owned enterprise groups should be established to safeguard the interests of the nation' (Guowuyuan Yanjiushi Ketizu 1994: 27). The documents also reflect a preoccupation with the state sector's 'getting big and getting strong' (zuo da zuo qiang做大做强) in order to ward off the advances of foreign multinationals. A 1996 report by an official with the State Economic and Trade Commission (SETC) made the case with reference to the civil aviation industry:

As China's economy is gradually linked to the international economy, there will be more and more foreign companies and large corporations in the domestic market. This means that the domestic market will become even more a part of the international market, such that enterprise groups that stay within the domestic market will be in direct contest with foreign companies and large corporations. Objectively speaking, compared to the strength of large foreign companies and corporations from abroad, we are at a considerable distance. The total number of aircraft of our three airline groups - Air China, China Eastern and China Southern - is less than America's ninth largest airline, Southwest Airlines. The combined assets of our four aircraft manufacturing enterprise groups - AVIC Xi'an Industry Aircraft Group, Shanghai Aviation Industrial Group, AVIC South Aviation Industry Group and Guizhou Aviation Industrial Group - is less than 50\% of the total assets of America's McDonnell Douglas. In the face of these powerful competitors, we must quickly adjust the organizational structure of enterprises; encourage competition; promote alliances and mergers; and make some strong enterprises that are in line with the country's industrial policy grow rapidly stronger. (Liu 1996: 2) 
Policymakers' concern with increasing the domestic market share of the 'Big Three' airlines provided the rationale for a state-led consolidation of the airlines market in the early 2000s (Eaton 2013).

In addition to 'safeguarding the interests of the nation' in the domestic market, policymakers expressed hope that state-owned large enterprises would lead the charge into the global marketplace. It was in the context of China's international trade negotiations that proponents of the large enterprise strategy began referring to the trial enterprises as the 'national team' (guojia dui国际队). In a 1997 speech, Vice Premier Wu Bangguo made the case in stark terms: 'If we could have ten or twelve internationally competitive large enterprises we wouldn't just be a "big" economy, we could become a "strong" economy; we could take our rightful place in the international economy' (Jin yi bu 1997: 1). Some documents even suggest that large enterprises ought to engage in Art of War style tactics in order to enhance their own position and undercut that of their competitors. In a 1995 speech addressing the challenges faced by the 'pilot' large enterprise groups in a liberalizing economy, Cheng Qingtai, a leading official of the large enterprise trials advised: 'We must not limit alliance formations to domestic enterprises; we should also make use of conflicting interests between international competitors and establish alliances with the competitors of our competitors; we must also consider attacking (chuji出击) international markets and a number of new market areas, such as third world markets.' (Chen 1995: 6)

\section{Weighing the Benefits of Monopoly}

One of the most interesting aspects of this collection of internal documents is the focus on weighing the pros and cons of monopoly. As discussed previously, a number of analysts argued, in Marxian terms, that monopolies were a natural outgrowth of capitalist development. Moreover, many contributors argued that under the right circumstances, as in post-war Japan, such monopolies could be effectively harnessed to the cause of driving national development. Yet, concerns about the downside of monopoly, expressed in the language of the liberal tradition of political economy, were also voiced at the time. Many of these worries bear striking resemblance to criticisms of actual business practices in the 'monopoly industries' (longduan hangye垄断行业) that have filled the mainland press in recent years.

These documents lend insight into the theoretical underpinnings of Chinese officials' support for the establishment of state-owned monopo- 
lies and oligopolies. One early piece, written by a researcher from the Tianjin branch of the Chinese Academy of Social Sciences (CASS) argued that the large enterprise strategy would naturally lead to monopoly:

Regardless of whether combinations take place within relatively loose enterprise groups, or within comparatively close-knit enterprise groups, the interests of the enterprise groups will drive expansion of their scale and increasingly high levels of concentration. Once a certain level is reached, this process will produce monopoly. As Li Ning pointed out: 'Once concentration develops to a certain level, one can say that monopoly will result as a matter of course.' The economy produces concentration and, past a certain point, concentration causes monopoly. This is a law of commodity economies. (Sun 1987: 31)

While many writers acknowledge the dangers of monopoly, some have argued that monopoly and competition are not, in fact, antithetical. One internal document argued:

Although enterprise groups do have monopoly characteristics, this does not mean that the existence of enterprise groups will stifle competition. In actual fact, just as enterprise groups have monopolistic features, due to, inter alia, the constant development of the economy as well as the internal structure of enterprise groups, they also have characteristics of competition. Enterprise groups are the unity of monopoly and competition. (Chen 1993: 20)

These 'characteristics of competition' include competition between enterprise groups; competition between enterprise groups and conventional enterprises; and competition between enterprises within the group (Chen 1993: 20-21). The ideas expressed in these articles offer a striking contrast to the familiar, neoclassical view of monopolies as aberrant departures from perfect competition to be remedied with such measures as deregulation and competition law. These documents reflect an eclectic view of monopoly, which combined Marxist and institutionalist scholars' views of the inevitability of monopoly capitalism with developmentalist perspectives on the benefits of monopolistic large enterprises for national development.

Yet such views were not held by all. Others looking into the future argued that the government ought to develop means of preventing monopoly in industries home to large enterprises. Then a newly-minted PhD from CASS and now vice chairman of the China Insurance Regulatory Commission, Chen Wenhui argued in a neibu journal in 1993 that although establishment of large enterprise groups could bring about economies of scale in industry as well as a more specialized division of labour, monopoly threatened to stymie these benefits. He characterized identification of the appropriate means of preventing monopoly as 'an 
important research topic' (Chen 1993: 25). Chen also expressed concern about the capacity of China's institutional environment to effectively constrain large enterprise groups from devolving into cronyism. Noting that large enterprise groups ought to be independent and self-financing, he argued that most of China's 55 pilot enterprises remained deeply, and problematically, entwined with government; one such pilot enterprise, the Heilongjiang Forest Industry Enterprise Group, was said to retain its own court system as well as its own forest police (Chen 1993: 22). In such 'administrative monopolies' (xingzheng longduan行政垄断), market competition was, in reality, a rigged 'game' in which government abused its dual role as both player and referee (ibid). The reasoning is strikingly similar to recent arguments for 'breaking monopoly' (dapo longduan 打 破垄断) made by 'New Right' economists such as Zhang Weiying (e.g. Zhang 2006).

The focus of this article is on ideas, but it is worth noting that these documents also have much to reveal about senior policymakers' views on practical matters of implementation, organization and bureaucracy. Throughout, one finds echoes of Chen's scepticism about the capacity of the Chinese state to effectively guide large enterprise groups. One particularly unvarnished piece, written by a State Planning Commission official in 1996, argued that large enterprise group experimentation was beset by a serious lack of coordination:

Why develop large enterprise groups? Policymakers (juececeng决策层), government departments and enterprises have understandings of this issue that are probably not entirely consistent. The aim of policymakers in the formation and development of enterprise groups is to improve the international competitiveness of our businesses and the economy. In the circumstances of China's continuous opening to the international economy, the aim is to make China's economy and industry able to survive, develop and, in the context of a fiercely competitive international market, secure an invincible position... But when these aims and background considerations arrive at the government departments and regions, they turn into a kind of assignment: they want to establish several or dozens of enterprise groups, not solve the problem of how to improve competitiveness. And at the enterprise level, they strive to be included in an enterprise group because after being included they can become a discrete planning unit and will have many conveniences (such as decisionmaking power) and benefits (such as status, a higher administrative rank and preferential policies). Very few, basically none, of these enterprises consider that the purpose of developing large groups is to avoid the risk of operating losses; stabilize market share, and; increase domestic and international competitiveness in production and business sales, domestic and international competitiveness. Because of variance in these aims, the experiment in establishing and developing 
enterprise groups is unsatisfactory, and there is even no way for them to carry things out or develop. (Jiang 1996: 11)

Others pointed out that while increasing industrial concentration did seem to be a feature of capitalist development and, thus, bound to emerge in China, the gradual, market-driven nature of the 'centralization of capital' in countries with a long history of capitalism was fundamentally unlike China's heavy-handed, administrative approach. One particularly controversial method of forming enterprises groups in China was so-called 'arranged marriages' (lalangpei拉郎配), in which government played the role of matchmaker between stronger and weaker enterprises, the results of which were often less than glowing (Zhang and Liang 1995: 16). In the manner described above, such matchmaking was often driven more by bureaucrats' interests in satisfying demands from on high than by objective considerations of the economic value of these pairings.

\section{Conclusion}

In shedding light on the ideational foundations of Chinese policymakers' embrace of the large enterprise group strategy in the first two decades of the reform period, the assembled documents offer insight into why Chinese policymakers chose this path. First, policymakers drew eclectically from the annals of economic history in forming the conclusion that mounting industrial policy in support of large enterprise group development could, if done well, accelerate China's economic development. From Marxian economics they learned that choosing a capitalist road, even one with Chinese characteristics, would lead inexorably towards monopoly. From the East Asian developmental states they learned that this was not necessarily a bad thing; the example set by Japan, in particular, seemed to suggest that judicious state guidance of the process of 'centralization of capital' could effectively steer enterprises away from cronyism and indolence and towards meeting national development objectives.

But the promised benefits of developing state-owned large enterprise groups were not defined purely in economic terms. The 'gradual encroachment' of this idea also clearly had a political dimension. In the context of a rapidly growing non-state sector and a teetering state sector, policymakers thought of state-owned large enterprises as key elements of the market-conforming model of state control they began to envision and work towards beginning from the late 1980s. While there was undoubtedly an element of Marxist-Leninist correctness behind internal 
debate about how the state could continue to exercise its constitutionally mandated 'leading role' in a liberalizing economy, the fears informing this debate seem to have been quite real. Indeed, the challenge facing them was immense: just how does a communist ruling party 'ride the tiger' of a marketizing economy? The blueprints in this category were truly few and this helps to explain why, despite the vast differences between the two countries, Singapore emerged as an important model for Chinese policymakers' efforts to transform themselves into marketembracing communist authoritarians while staying on the tiger's back.

This article is not concerned with current affairs but, arguably, its content is helpful to making sense of important developments in recent years. As the other contributions to this volume attest, the 'advancing state' (guojin国进) has become a mainstay of debate among Chinese intellectuals and within government since the global financial crisis. Strikingly, many of the protagonists in the events linked to guojin, central SOEs, were part of the national team of pilot enterprises nurtured by the central government in the 1990s. While references to the large enterprise strategy within Chinese officialdom petered out in the late 1990s - partly because Li Peng was replaced by Zhu Rongji and partly because the Asian Financial Crisis had tarnished the image of Asian business groups - one finds a high degree of ideational continuity in current discussions about state sector development. For example, under the leadership of Li Rongrong, inaugural director of the centrallevel State Owned Assets Supervision and Administration Commission (SASAC), mergers between central SOEs were firmly encouraged, and sometimes outright demanded by SASAC, in the name of SOEs 'going big and going strong' (zuo da zuo qiang做大做强).

Yet, while the policies are similar, this is not simply a story of continuity. In comparison to official views from earlier decades examined here, there is now much less consensus that such interventions are, in fact, appropriate and legitimate. In pockets of Chinese officialdom as well as among prominent scholars, ideas about the appropriate role of government in the economy are regularly framed in the language of neoclassical economics and, often, in neoliberal terms. Indeed, arguments for 'breaking monopoly' (dapo longduan打破垄断), which have filled the pages of such pro-market periodicals as The Economic Observer (jingji guancha bao 经济观察报) in recent years, are miles from the eclectic state socialist ideas that informed the large enterprise strategy. Indeed, many such pieces assume that the rightful path forward-i.e. more liberalization, less industrial policy - is self-evident and the only thing 
holding current practice in place is powerful interests in the state sector (e.g. Zhang 2006). Along these lines, renowned policy economist $\mathrm{Wu}$ Jinglian (2009) argued in a widely read Caijing op-ed that 'pushing the reform of the state-owned monopolies and that of the political system means that the government will have to reform itself. Consequently, reform has entered a more difficult battle and progress has slowed significantly.' In the coming years, high-stakes policy choices in the state sector will certainly be shaped by powerful interests, but the contest will also be over ideas.

Sarah Eaton is a University Lecturer in the Political Economy of China in the School of Interdisciplinary Area Studies at the University of Oxford. Her current research is concerned with various aspects of state capitalism in reform-era China. She welcomes comments on this piece at sarah.eaton@area. ox.ac.uk.

\section{Acknowledgments}

The author is grateful for use of the library facilities at the University Services Centre for China Studies at the Chinese University of Hong Kong in April 2012. The research for this project was made possible by funding from the Social Sciences and Humanities Research Council of Canada (Post-Doctoral Award No. 7562011 0371). She received helpful feedback on an early draft of this paper from participants at a conference on 'SOE Reform in China' hosted by the Asia Research Centre at the Copenhagen Business School held on 17-18 December 2012. Valuable comments were also received in a seminar held at the University of Heidelberg's Institute of Chinese Studies on 22 April 2013. Genia Kostka also provided helpful comments.

\section{NOTES}

1 The Jingji Yanjiu Cankao Ziliao series of documents covers 1985 to 1997. The Neibu Wengao documents are from 1993 to 1999. Gaige Neican documents cover 1994 to 2002.

2 The following two paragraphs draw from Eaton (2013): 66-70.

3 Chapter 1, Article 7 of the Constitution of the People's Republic of China reads: 'The state economy is the sector of socialist economy under ownership by the whole people; it is the leading force in the national economy. The state ensures the consolidation and development of the state economy.' 


\section{REFERENCES}

Blyth, M. 2002. Great Transformations: Economic Ideas and Institutional Change in the Twentieth Century. New York: Cambridge University Press.

Brødsgaard, K. E. 2012. 'Politics and Business Group Formation in China: The Party in Control?' The China Quarterly 211: 624-648.

Chen qingtai zai guojia shidian qiye jituan gongzuo huiyi shang de jianghua [Chen Qingtai's Speech to the Conference on National Pilot Enterprises] 1995. Jingji yanjiu cankao ziliao [Reference Materials for Economic Research] 83: 2-10.

Chen, W. H. 1993. 'Dangqian fazhan qiye jituan xuyao yanjiu de ji ge wenti' [Several Issues Related to Current Development of Enterprise Groups Needing Study]. Jingii yanjiu cankao ziliao [Reference Materials for Economic Research] 15 (October 20): 23-26.

Eaton, S. 2011. China's State Capitalist Turn: Political Economy of the Advancing State. Unpublished dissertation, University of Toronto.

Eaton, S. 2013. 'Political Economy of the Advancing State: The Case of China's Airlines Reform'. The China Journal 69: 64-86.

Guowuyuan Yanjiushi Ketizu [State Council Research Office Research Group] 1994. 'Wo guo suoyouzhi jiegou biange de qushi he duice yanjiu zong baogao' [Research Report on Trends in Ownership Change and Countermeasures]. Jingji yanjiu cankao ziliao [Reference Materials for Economic Research] 43 (March 16): 1-35.

Heilmann, S., and L. Shih. 2013. 'The Rise of Industrial Policy in China'. Harvard-Yenching Institute Working Paper Series. Available at: http:/ / www.harvard-yenching.org/ sites/harvard-yenching.org/files/featurefiles/Sebastian $\% 20$ Heilmann $\% 20$ and $\% 20$ Lea\%20Shih_The\%20Rise\%20of\%20Industrial\%20Policy\%20in\%20China \%2019782012.pdf (accessed 24 April 2013).

Jiang, A. 1996. 'Fazhan da qiye jituan de tiaojian, zhangai ji duice' [Conditions for the Development of Large Enterprise Groups as well as Obstacles and Countermeasures]. Jingji yanjiu cankao ziliao [Reference Materials for Economic Research] 58: 11-15.

'Jin yi bu guanche da gongsi, da jituan zhanlüe' [Further Implement the Large Company, Large Enterprise Strategy]. 1997. Jituan jingji yanjiu [Enterprise Group Economic Research] 8: 1.

Kang, H. J. 1989. 'Longduan wei bi dailai tingzhi he fuxiu' [Monopoly Need Not Bring Stagnation and Decadence]. Jingji yanjiu cankao ziliao [Reference Materials for Economic Research] 36 (March 7): 2-15.

Kennedy, S. 2005a. The Business of Lobbying in China. Cambridge: Harvard University Press.

Kennedy, S. 2005b. 'China's Porous Protectionism: The Changing Political Economy of Trade Policy'. Political Science Quarterly 120 (3): 407-432.

Keynes, J. M. [1936] 1997. The General Theory of Employment, Interest, and Money. Amherst, NY: Prometheus Books.

Li, C. 2011. 'China's Midterm Jockeying: Gearing Up for 2012 (Part 4: Top Leaders of Major State-Owned Enterprises)'. China Leadership Monitor 34.

Li, P. Y. 1989. 'Guowai chanye zhengce de bijiao yanjiu' [A Comparative Study of Industrial Policy in Other Countries]. Jingji yanjiu cankao ziliao [Reference Materials for Economic Research] 166 (October 29): 1-15

Liu, D. W. 1996. 'Guanyu qiye jituanhua zhanlüe de sikao' [Thoughts on the Enterprise Group Strategy]. Jingji yanjiu cankao ziliao [Reference Materials for Economic Research] 58 (April 12): 2-10.

Ma, H. 1989. 'Chongfen fahui da qiye zai shehui zhuyi xiandaihua jianshe zhong de gugan zuoyong' [Fully Realize the Backbone Function of Large Enterprises in the Socialist Modernization Drive]. Speech on 24 September 1989 at the Zhongguo Daxing Qiye 
Fazhan Wenti Zuotanhui (Forum on the Development of China's Large Enterprises), reprinted in Guanli shijie (Management World) 6: 2.

Nolan, P. 2001. China and the Global Economy: National Champions, Industrial Policy and the Big Business Revolution. Houndsmill: Palgrave.

Pearson, M. 2005. 'The Business of Governing Business in China: Institutions and Norms of the Emerging Regulatory State'. World Politics 57 (2): 296-322.

Sheng, G. J. 1997. 'Lüelun guoyou jingji de kongzhili' [Strategic Discussion of the Capacity to Control the State Economy]. Neibu Wengao [Internal Reports] 22: 1-3.

Steinberg, D., and V. Shih. 2012. 'Interest Group Influence in Authoritarian States: The Political Determinants of Chinese Exchange Rate Policy'. Comparative Political Studies 45 (11): 1405-1434.

Steinfeld, E. S. 2006 'Market Visions: The Interplay of Ideas and Institutions in Chinese Financial Restructuring' in Lowell Dittmer and Guoli Liu, eds. China's Deep Reform: Domestic Politics in Transition, Lanham, MD: Rowman \& Littlefield Publishers, pp. 471-492.

Sun, Z. X. 1987. 'Zhongguo de xinxing jingji zuzhi-qiye jituan' [China's New Economic Organization -Enterprise Groups]. Jingji yanjiu cankao ziliao [Reference Materials for Economic Research] 31 (February 25): 3-11.

Sutherland, D. 2003. China's Large Enterprises and the Challenge of Late Industrialisation. London: Routledge Curzon.

Sutherland, D., and P. Guest. 2010. 'The Impact of Business Group Affiliation on Performance: Evidence from China's "National Champions"'. Cambridge Journal of Economics 34 (4): 617-631.

Tong, D., and Y. M. Song. 1986. 'Horizontal Economic Integration is a Beachhead to Launch Urban Reform'. Chinese Economy 20 (2): 26-35.

Walter, C., and F. Howie. 2010. Red Capitalism: The Fragile Financial Foundations of China's Extraordinary Rise. Hong Kong: John Wiley \& Sons.

Walter C., and F. Howie. 2006. Privatizing China. Hong Kong: John Wiley \& Sons.

Wu, J. L. 2009. 《中国经济 60 年》(The Chinese Economy at 60), Sept. 28. Caijing. Available at: http:/ / magazine.caijing.com.cn/2009-09-27/110266175.html (accessed 24 May 2011).

Xing, T. 1988. 'Gao huo dazhongxing qiye de liang ge bu ke fenge de huanjie' [Two Inseparable Aspects of Enlivening Large and Medium-Sized Enterprises]. Jingji yanjiu cankao ziliao [Reference Materials for Economic Research] 82 (May 13): 17-24.

Xü X. Y. 1989. 'Guowai qiye jituan de zuzhi yu guanli' [Organization and Management of Foreign Enterprise Groups]. Jingji yanjiu cankao ziliao [Reference Materials for Economic Research] 166: 16-22.

Yang, G. B., and Y. J. Li. 2008. 'Zhongguo zhengzhi guocheng zhong de liyi jituan ji qi zhili' [Interest Groups and their Governance in the Chinese Political Process]. Xue hai [Academia Bimestris] 2: 55-62.

Yin, G. H., and H. L. Jia. 1987. 'Dali fazhan wo guo de qiye jituan' [Vigorously Develop China's Enterprise Groups]. Jingji yanjiu cankao ziliao [Reference Materials for Economic Research] 25 (April 15): 2-7.

Zhang, W. Y. 2006. 'Lixing sikao zhongguo gaige' [Rational Thoughts on Chinese Reform]. Caizheng jie [Money China] 6: 72-79.

Zhang, Z. J., and X. Liang. 1995. 'Ba wo guo qiye jituan jianli zai xiandai qiye zhidu de jichu shang' [Establish Chinese Enterprise Groups on the Basis of the Modern Enterprise System]. Jingji yanjiu cankao ziliao [Reference Materials for Economic Research] 132 (August 26): 16-23.

Zhou, F. S. 1995. 'Lun qiye jituan muzi gongsi chanquan guanxi' [On enterprise group's ownership relations between parent companies and subsidiaries]. Jingji yanjiu cankao ziliao [Reference Materials for Economic Research] 190 (December 11): 2-50. 